\title{
Fire Activity and Their Relationship with the Global Fire Weather Index Database Components in Guinea
}

\author{
Mamadou Baïlo Barry \\ Laboratoire de Physique de l'Atmosphère et de l'Océan Siméon Fongang (LPAO-SF) \\ Université Cheikh Anta Diop, BP: 5085, Dakar, Senegal and Laboratore de Physique \\ Institut Supérieur des Sciences de l'Education de Guinée (ISSEG) \\ BP: 795, Conakry, Guinea \\ E-mail: boubailomariam@yahoo.fr
}

Daouda Badiane

Laboratoire de Physique de l'Atmosphère et de l'Océan Siméon Fongang (LPAO-SF)

Université Cheikh Anta Diop, BP: 5085, Dakar, Senegal

Saïdou Moustapha Sall

Laboratoire de Physique de l'Atmosphère et de l'Océan Siméon Fongang (LPAO-SF)

Université Cheikh Anta Diop, BP: 5085, Dakar, Senegal

Moussa Diakhaté

Laboratoire de Physique de l'Atmosphère et de l'Océan Siméon Fongang (LPAO-SF)

Université Cheikh Anta Diop, BP: 5085, Dakar, Senegal

Habib Senghor

Laboratoire de Physique de l'Atmosphère et de l'Océan Siméon Fongang (LPAO-SF)

Université Cheikh Anta Diop, BP: 5085, Dakar, Senegal

Received: March 4, 2019 Accepted: March 22, 2019 Published: April 3, 2019

doi:10.5296/emsd.v8i2.14602 URL: https://doi.org/10.5296/emsd.v8i2.14602 
Abstract

The relationships between the Canadian Fire Weather Index (FWI) System components and the monthly burned area as well as the number of active fire which has taken from Moderate Resolution Imaging Spectroradiometer (MODIS) Aqua/TERRA were investigated in 32 Guinean stations between 2003 and 2013. A statistical analysis based on a multi-linear regression model was used to estimate the skills of FWI components on the predictability of burned area and active fire. This statistical analysis gave performances explaining between 16 to $79 \%$ of the variance for the burned areas and between 29 and $82 \%$ of the variance for the number of fires $(\mathrm{P}<0.0001)$ at lag 0 . Respectively 16 to $79 \%$ and 29 to $82 \%$ of the variance of the burned areas and variance for the number of fires $(\mathrm{P}<0.0001)$ at lag0 can be explained based on the same statistical analysis. All the combinations used gave significant performances to predict the burned areas and active fire on the monthly timescale in all stations excepted Fria and Yomou where the predictability of the burned areas was not obvious. We obtained a significant correlation between the average over all of the stations of burned areas, active fires and FWI composites with percentage of variance between (75 to 84\% and 29 to $77 \%$ ) for active fires and burned areas at lag0 respectively. While for burned area peak (January), the skill of the predictability remains significant only one month in advance, for the active fires, the model remains skilful 1 to 3 months in advance. Results also showed that active fires are more related to fire behavior indices while the burned areas are related to the fine fuel moisture codes. These outcomes have implications for seasonal forecasting of active fire events and burned areas based on FWI components, as significant predictability is found from 1 to 3 months and one month before respectively.

Keywords: Active fire, Burned area, FWI components, Guinea

\section{Introduction}

The fire has an important role in the structure and functioning of ecosystems (Archibald et al., 2013). It is commonly used by people for various purposes in function of socio-economic activities and geographic areas as a management tool. Fire's satellite observations could be obtained with different time resolutions : daily (Alonso et al.,2003, Lozana et al., 2007, Alberson et al., 2009, Wottan et al., 2010, Padilla et Vega, 2011, Sakr et al., 2011), monthly (Preister et al., 2004, Boulanger et al., 2014), and yearly (Prestemon et Butry, 2005, Hu et Zhou, 2014, Karouni et al., 2014). Some authors consider fire as a planning tool of the savannas (Dupuy, 1968, Jeffrey et Humphrey, 1975), while others particularly point it out as the ecological, economic and social threat (Sheehan et Hewitt, 1969). The long term effects of bush fires on ecosystems have been highlighted by several recent studies (Scholze et al., 2006; Miller et al., 2013; Reed-Dustin, 2015; Doerr and Santín, 2016; Hagmann et al., 2018; Guiterman et al., 2018; Inoue et al., 2018) which demonstrated their disruptive role on the water cycle, soil absorption capacity, aerosol emission, climate change, vegetation dynamics and soil fertility. The estimation of the danger of fire is a way to quantify the potential or capacity of a fire to start, spread and cause damage (Merrill et Alexander, 1987). In the current context of climate change, it is therefore important to have indicators of risk of bush fires to better define the management policies of ecosystems. 
The Fire Weather Index (FWI) has been developed by the Canadian method, involving weather parameters such as wind, relative humidity, surface temperature, and rain to characterize the level of bush fire risk. The evaluation system of the dangers of fires (Stocks et al., 1989) includes two subsystems currently used: the Canadian fire weather index (Van Wagenr, 1987) system and the Canadian system of fire forecasting (PBF) (Group Fire Danger of Forests Canada 1992). This system uses a method so-called Canadian method of the fire weather index (Turner and Lawson, 1978, Van and Pickett, 1985). This method was widely applied over North America and Europe where observation stations are very dense and the results were very conclusive. This index is derived from different indices characterizing the state of fuel or the weather conditions on a specific point of the globe. These indices are:

$>$ The Fine Fuel Moisture Code (FFMC) is a numeric rating of the moisture content of litter and other cured fine fuels. This code is an indicator of the relative ease of ignition and the flammability of fine fuel.

$>$ The Drought Code (DC) is a numeric rating of the average moisture content of deep, compact organic layers. This code is a useful indicator of seasonal drought effects on forest fuels and the amount of smoldering in deep duff layers and large logs.

$>$ The Duff Moisture Code (DMC) is a numeric rating of the average moisture content of loosely compacted organic layers of moderate depth. This code gives an indication of fuel consumption in moderate duff layers and medium-size woody material.

$>$ The Initial Spread Index (ISI) is a numeric rating of the expected rate of fire spread. It combines the effects of wind and the FFMC on a rate of spread without the influence of variable quantities of fuel.

$>$ The Buildup Index (BUI) is a numeric rating of the total amount of fuel available for combustion. It combines the DMC and DC.

$>$ The Fire Weather Index (FWI) is a numeric rating of fire intensity. It combines the Initial Spread Index and the Buildup Index. It is suitable as a general index of fire danger throughout the forested areas of Canada.

In West Africa, many types of research were conducted on the spatial and temporal distribution of the fires activities (Millimono et al., 2017, Mbow, 2000, Sow, 2012, Valea, 2010, Barry et al., 2018). For better management, it is important to have preventive measures of bush fire with early warning systems through on fire's occurrences. In this study, FWI's products from the National Aeronautics and Space Administration (NASA) through the Goddard Institute for Space Studies (GISS) are used. All details of these products are described in (Field et al., 2015). The FWI components have been widely used to characterize bush fires in many countries (Carvalho et al., 2008, Davies et Legg, 2016, De Groot et al., 2007) and the results are very interesting for saving the environment. Figure1 shows the structure of the fire weather index's calculation. 


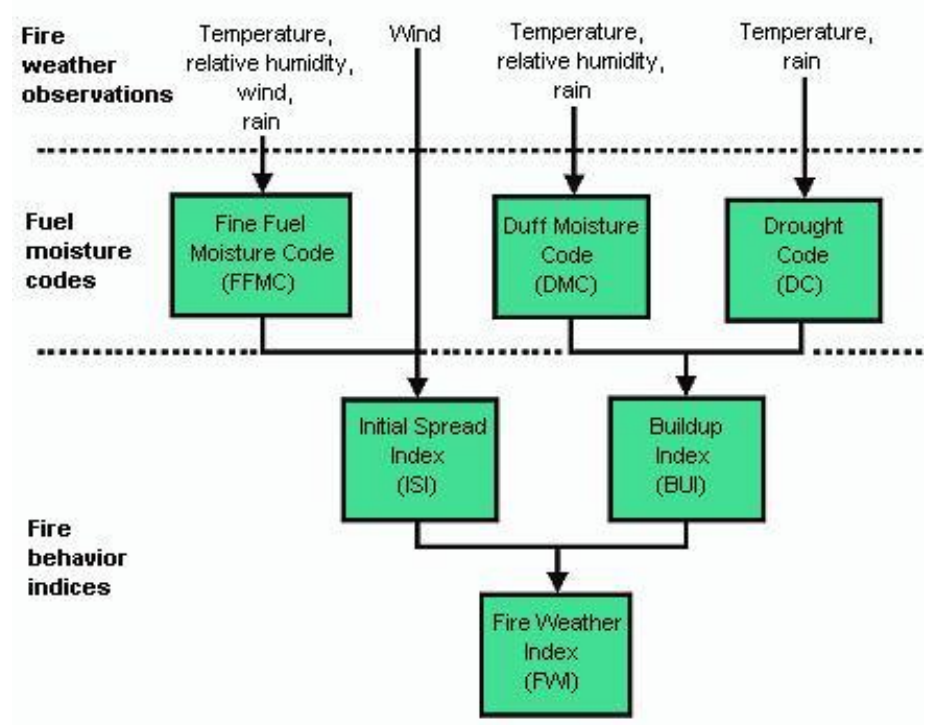

Figure 1. Basic structure of the fire weather index 's calculation (Van Wagner, 1987)

The most active world fire areas (Africa and Latin America) still require modeling efforts (Costefreda-Aumedes et al., 2018) and few studies are devoted to fires in these areas of high forest fire activities (Chuevieco et al., 2008, Krawchuk et al., 2009 , Knorr et al., 2014, Bedia et al., 2015). For this purpose, this study seeks the relationship between FWI components, burned areas and active fires on a monthly time scale based on the combinations of FWI components as predictors. A statistical analysis using a linear prediction model is used to define the performance of the two indices to predict bush fire on the different sites selected for this study at the national level.

The main contributions of this study are outlined as follows:

- The predictability of active fires and burned areas in Guinea at the whole scale and in 32 specific sites was highlighted.

- For each site, the FWI components that most characterize active fires and burned areas are identified and ranked in order of importance.

- The dependence of the predictability with the nature of the vegetation cover is highlighted.

The paper is organized as follows. In Section 2, data and methodology (including the presentation of the study area) used in this study are described. Section 3 is accorded to results highlights and discussion. Finally, section 4 presents the conclusion.

\section{Data and Methods}

\subsection{Study Area}

The vegetation of Guinea, according to the annual report of 2015 of the Ministry of Environment, Water, and Forests (MEEF), consists of $1.02 \%$ of mangroves, 2.85 of humid forests, $6.51 \%$ of dense forests, $43.26 \%$ wooded savannah, $6.9 \%$ cropland and $30.5 \%$ fallow. 
According to the Tropical-Guinea Forestry Action Plan (TFAP, 1988) and the Report on Forest Policy and National Forest Action Plan of 2010, the forest patrimony would amount to about 13186000 hectares (53,64\% of the national territory). The vast Savannah encountered in Guinea, $43.26 \%$ of the national territory, combined with slash-and-burn activities in most of the country, offers a very exposed environment to the negatives effects of bush fires on the ecosystems. These savannas are mainly found in the areas of upper and middle Guinea and part of Forest Guinea.

According to the 2015 annual report of the National Directorate of Water and Forests, the average annual deforestation rate is 30000 ha per year against an annual reforestation rate of 1043 ha. That means a negative difference of 19850 ha each year over the period from 2004 to 2013. In the same report, the average area of forests devastated by bush fires between 2004 and 2013 has been estimated to 205.318 ha, although the trend has been declining since 2009 . Statistics on the annual afforestation rate, the deforestation rate and the area under bush fire damage according to the National Directorate of Water and Forests (DNEF) are shown in Table 1.

Table 1. Statistics of vegetation cover in Guinea from 2003 to 2014 (see DNEF report, 2015)

\begin{tabular}{|l|l|l|l|l|l|l|l|l|l|l|}
\hline Years & 2004 & 2005 & 2006 & 2007 & 2008 & 2009 & 2010 & 2011 & 2012 & 2013 \\
\hline $\begin{array}{l}\text { Reforested } \\
\text { areas per } \\
\text { year (ha) }\end{array}$ & 1070,29 & 2500 & 2828,54 & 337,35 & 511,89 & 404,36 & 908,22 & 938,51 & 618,25 & 317,72 \\
\hline $\begin{array}{l}\text { Deforestation } \\
\text { rate (ha/ } \\
\text { year) }\end{array}$ & 30000 & 30000 & 30000 & 30000 & 30000 & 30000 & 30000 & 30000 & 30000 & 30000 \\
\hline $\begin{array}{l}\text { Total area of } \\
\text { forest burned } \\
\text { (ha/year) }\end{array}$ & 333001 & 332950 & 333153,5 & 332972,5 & 332 & 377,5 & 100402 & 98384,5 & 95455,84 & 93532 \\
\hline
\end{tabular}

32 sites were selected for this study in order to specify in detail, the level of risk across the country. These sites are shown in Figure 2 and the main characteristics of each site are described in Table 2. 


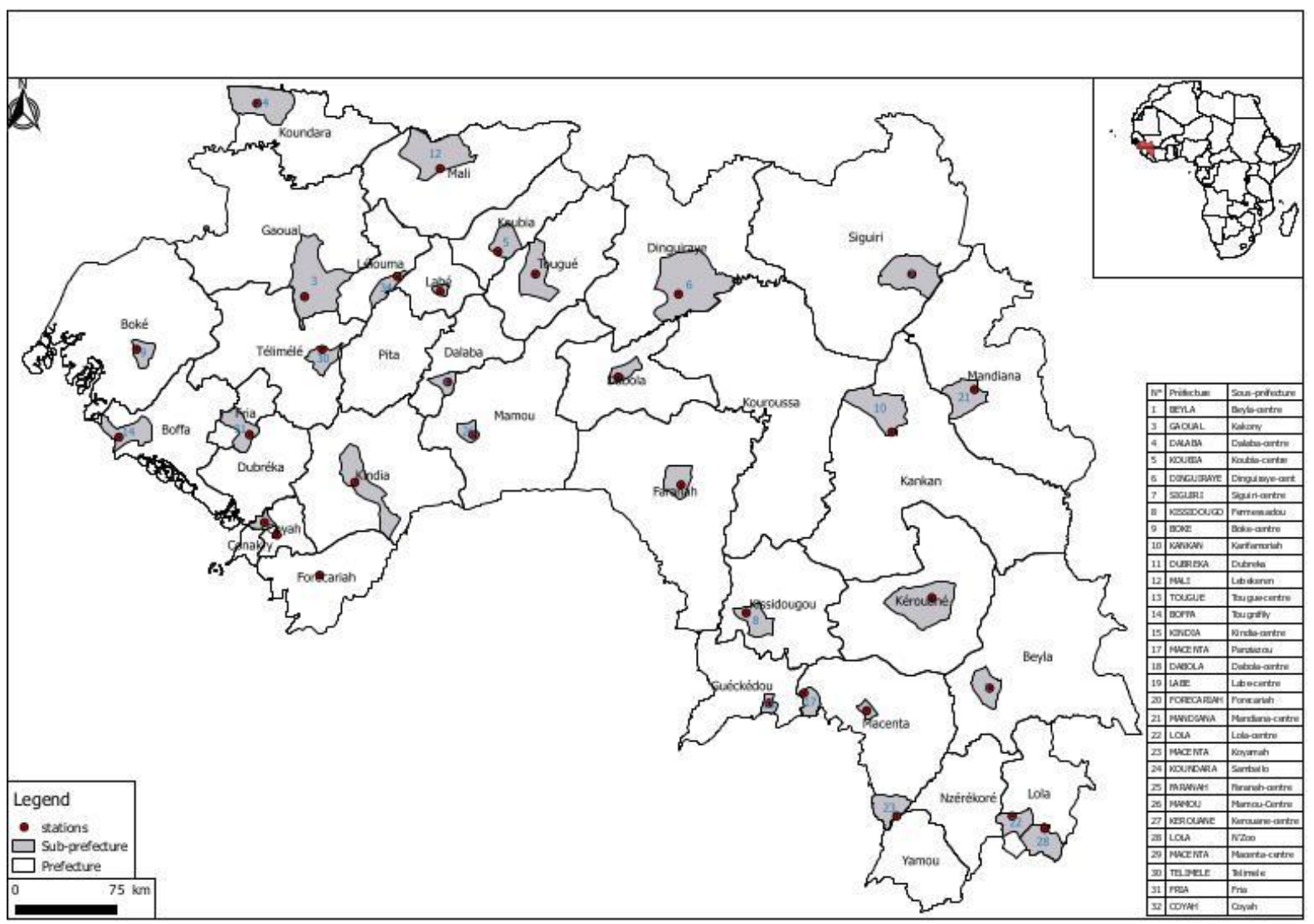

Figure 2. Location of Guinea on the African map and sites of interest identification

Table 2. Main characteristics of the stations considered in the present study (cf National Directorate of Water and Forests (DNEF))

\begin{tabular}{|l|l|l|l|l|l|l|}
\hline Station & $\begin{array}{l}\text { Longitude } \\
\left({ }^{\circ} \mathrm{W}\right)\end{array}$ & $\begin{array}{l}\text { Latitude } \\
\left({ }^{\circ} \mathrm{N}\right)\end{array}$ & Altitude & $\begin{array}{l}\text { Beginning } \\
\text { data }\end{array}$ & End date & $\begin{array}{l}\text { Number } \\
\text { of years }\end{array}$ \\
\hline Coyah & 13.23 & 09.42 & 20 & January 2003 & $\begin{array}{l}\text { December } \\
2013\end{array}$ & 11 \\
\hline Dubréka & 13.28 & 09.47 & 15 & January 2003 & $\begin{array}{l}\text { December } \\
2013\end{array}$ & 11 \\
\hline Kindia & 12.52 & 10.03 & 458 & January 2003 & $\begin{array}{l}\text { December } \\
2013\end{array}$ & 11 \\
\hline Forékariah & 13.06 & 09.26 & 47 & January 2003 & $\begin{array}{l}\text { December } \\
2013\end{array}$ & 11 \\
\hline Fria & 13.34 & 10.22 & 160 & January 2003 & $\begin{array}{l}\text { December } \\
2013\end{array}$ & 11 \\
\hline Boffa & 14.26 & 10.21 & 30 & January 2003 & $\begin{array}{l}\text { December } \\
2013\end{array}$ & 11 \\
\hline Boké & 14.19 & 10.56 & 69 & January 2003 & $\begin{array}{l}\text { December } \\
2013\end{array}$ & 11 \\
\hline Téléminè & 13.05 & 10.56 & 650 & January 2003 & $\begin{array}{l}\text { December } \\
2013\end{array}$ & 11 \\
\hline Labé & 12.18 & 11.19 & 1050 & January 2003 & $\begin{array}{l}\text { December } \\
2013\end{array}$ & 11 \\
\hline Dalaba & 12.15 & 10.43 & 1202 & January 2003 & $\begin{array}{l}\text { December } \\
2013\end{array}$ & 11 \\
\hline Mamou & 12.05 & 10.20 & 782 & January 2003 & $\begin{array}{l}\text { December } \\
2013\end{array}$ & 11 \\
\hline
\end{tabular}




\begin{tabular}{|l|l|l|l|l|l|l|} 
Mali & 12.18 & 12.08 & 1464 & January 2003 & $\begin{array}{l}\text { December } \\
2013\end{array}$ & 11 \\
\cline { 1 - 5 } Tougué & 11.40 & 11.26 & 868 & January 2003 & $\begin{array}{l}\text { December } \\
2013\end{array}$ & 11 \\
\cline { 1 - 5 }
\end{tabular}

\begin{tabular}{|l|l|l|l|l|l|l|} 
Tougué & 11.40 & 11.26 & 868 & January 2003 & $\begin{array}{l}\text { December } \\
2013\end{array}$ & 11 \\
\hline Gaoual & 13.12 & 11.17 & 100 & January 2003 & $\begin{array}{l}\text { December } \\
2013\end{array}$ & 11 \\
\hline Lélouma & 12.35 & 11.25 & 892.35 & January 2003 & $\begin{array}{l}\text { December } \\
2013\end{array}$ & 11 \\
\hline
\end{tabular}

\begin{tabular}{|l|l|l|l|l|l|l|}
\hline Koubia & 11.55 & 11.35 & 722 & January 2003 & $\begin{array}{l}2013 \\
\text { December } \\
2013\end{array}$ & 11 \\
\hline Koundara & 13.31 & 12.34 & 90 & January 2003 & $\begin{array}{l}\text { December } \\
2013\end{array}$ & 11 \\
\hline
\end{tabular}

\begin{tabular}{|l|l|l|l|l|l|l|}
\hline Kankan & 09.18 & 10.23 & 376 & January 2003 & $\begin{array}{l}\text { December } \\
2013\end{array}$ & 11 \\
\hline Faranah & 10.42 & 10.02 & 358 & January 2003 & $\begin{array}{l}\text { December } \\
2013\end{array}$ & 11 \\
\hline Kouroussa & 09.53 & 08.39 & 372 & January 2003 & Decer & 11 \\
\hline
\end{tabular}

\begin{tabular}{|l|l|l|l|l|l|l|}
\hline Dinguiraye & 10.43 & 11.18 & 490 & January 2003 & $\begin{array}{l}\text { December } \\
2013\end{array}$ & 11 \\
\hline Kérouané & 09.02 & 09.17 & 510 & January 2003 & $\begin{array}{l}\text { December } \\
2013\end{array}$ & 11 \\
\hline Siguiri & 09.10 & 11.26 & 361 & January 2003 & $\begin{array}{l}\text { December } \\
2013\end{array}$ & 11 \\
\hline
\end{tabular}

\begin{tabular}{|l|l|l|l|l|l|l|}
\hline Siguiri & 09.10 & 11.26 & 361 & January 2003 & $\begin{array}{l}\text { December } \\
2013\end{array}$ & 11 \\
\hline Dabola & 11.07 & 10.45 & 438 & January 2003 & $\begin{array}{l}\text { December } \\
2013\end{array}$ & 11 \\
\hline Mandiana & 08.45 & 10.40 & 388 & January 2003 & $\begin{array}{l}\text { December } \\
2013\end{array}$ & 11 \\
\hline N'Zérékoré & $08^{\circ} 17$ & 07.45 & 467 & January 2003 & $\begin{array}{l}\text { December } \\
2013\end{array}$ & 11 \\
\hline Macenta & $09^{\circ} 28$ & 08.32 & 542 & January 2003 & $\begin{array}{l}\text { December } \\
2013\end{array}$ & 11 \\
\hline Kissidougou & $10^{\circ} 16$ & 09.11 & 524 & January 2003 & $\begin{array}{l}\text { December } \\
2013\end{array}$ & 11 \\
\hline Guéguécdou & $10^{\circ} 07$ & 08.35 & 425 & January 2003 & $\begin{array}{l}\text { December } \\
2013\end{array}$ & 11 \\
\hline Beyla & $08^{\circ} 39$ & 08.41 & 695 & January 2003 & $\begin{array}{l}\text { December } \\
2013\end{array}$ & 11 \\
\hline Lola & $08^{\circ} 30$ & 07.50 & 501 & January 2003 & $\begin{array}{l}\text { December } \\
2013\end{array}$ & 11 \\
\hline Yomou & $09^{\circ} 16$ & 07.50 & 48 & January 2003 & $\begin{array}{l}\text { December } \\
2013\end{array}$ & 11 \\
\hline
\end{tabular}

\subsection{The Burned Areas}

As described in burned area products User Guide Version 3.0.1 of MODIS (Boschetti, 2018), the burned areas are characterized by deposits of charcoal and ash, removal of vegetation, and alteration of the vegetation structure (Roy et al., 1999). To map the burned areas, the MODIS algorithm takes advantage of these spectral, temporal, and structural changes. The algorithm detects the approximate date of burning at $500 \mathrm{~m}$ resolution by locating the occurrence of rapid changes in daily surface reflectance. A bidirectional reflectance model is used to deal with angular variations found in the satellite. The bidirectional reflectance model-based change detection algorithm developed for the MCD45 product is a generic change detection method that is applied independently to geolocated pixels over a long time series (weeks to months) of reflectance observations (Roy et al., 2002, Roy et al., 2005). Reflectance sensed 


\section{Macrothink}

within a temporal window of a fixed number of days is used to predict the reflectance on a subsequent day. A statistical measure is used to determine if the difference between the predicted and observed reflectance has a significant change of interest. Rather than attempting to minimize the directional information present in a wide field of view satellite data by compositing, or by the use of spectral indices, this information is used to model the directional dependence of reflectance. This provides a semi-physically based method to predict change in reflectance from the previous state. However, it allows MODIS to map only the spatial extent of recent fires and excludes fires that occur- red in previous seasons or years.

\subsection{The Active Fire}

As described by Giglio et al., (2003); Giglio, (2010); Giglio, (2015) and Giglo et al., (2016), the detection algorithm of active fire uses native (i.e., unprojected swath) 4-, 11-, and 12- $\mu \mathrm{m}$ brightness temperatures derived from the corresponding 1-km MODIS channels, denoted by T4, T11, and T12, respectively. And, for daytime observations, 0.65-, 0.86-, and 2.1- $\mu \mathrm{m}$ reflectance (denoted by $\rho 0.65, \rho 0.86$, and $\rho 2.1$, respectively), aggregated to $1-\mathrm{km}$ spatial resolution are used. Table 3. provides a summary of all MODIS bands used in the algorithm.

Table 3. Summary of MODIS channels used in the detection algorithm and ingested from the Collection 6 MODIS Level-1B radiance product (MOD021KM/MYD021KM). Details regarding the blending of bands 21 and 22 may be found in (Giglo et al., 2003)

\begin{tabular}{|l|l|l|}
\hline $\begin{array}{l}\text { Channel } \\
\text { number }\end{array}$ & $\begin{array}{l}\text { Central } \\
\text { Wavelength } \\
(\mu \mathrm{m})\end{array}$ & \multicolumn{1}{c|}{ Purpose } \\
\hline 1 & 0.65 & Sunglint and coastal false alarm rejection; cloud masking. \\
\hline 2 & 0.86 & Bright surface, sun glint, and coastal false alarm rejection; cloud masking. \\
\hline 7 & 2.1 & Sunglint and coastal false alarm rejection. \\
\hline 21 & 4.0 & High-range channel for active fire detection. \\
\hline 22 & 4.0 & Low-range channel for active fire detection. \\
\hline 31 & 11.0 & Active fire detection, cloud masking, forest clearing rejection. \\
\hline 32 & 12.0 & Cloud masking. \\
\hline
\end{tabular}

The goal of the detection algorithm is to identify "fire pixels" that contain one or more active burning fires at the time of the satellite overpass. To this end, the algorithm ultimately classifies each pixel of the MODIS swath as missing data, cloud, non-fire, fire, or unknown. For the sake of backward compatibility, the collection 6 fire products actually use a slightly larger set of classes that can be uniquely mapped into the five classes defined here. Framing the algorithm output in terms of these five classes, however, greatly simplifies the subsequent description of the collection 6 algorithm. Full details may be found in the product User's Guide (Giglo, 2015).

The MODIS active fire products have been evaluated in different studies (e.g.,Csiszar et al., 2006; Hawbaker et al., 2008; Schroeder et al., 2008; Tanpipat et al., 2009; Freeborn et al., 2014; He and Li, 2011; De Klerk et al., 2008; Hantson et al., 2013; Maier et al., 2013), and in the context of optimizing the global MODIS algorithm for use within a specific region (e.g. Cheng et al., 2013; Ressl et al., 2009; Wang et al., 2007). 


\subsection{The Fire Weather Index database}

The FWI components used are the Global FWI v1p5 of the fire weather index and they are available online at ftp.nccs.nasa.gov or on the website of the Center for research in climate and society at the University of Colombia (http://iridl.ldeo.columbia.edu/SOURCES /.GISS/.GlobalFWI/). With 0.5 latitudes and 0.66 longitude grid resolution and a daily temporal resolution. The development and testing of the Global Fire WEather Database (GFWED) details can be found in Field et al., 2015). Applications of the FWI system can be found in Taylor and Alexander (2006), and the technical descriptions are provided by Field et al., 2015 and Dowdy et al., 2009. The GFWED can be used for analyzing historical relationships between fire weather and fire activity at continental and global scales, in identifying large-scale atmosphere-ocean controls on fire weather, and calibration of FWIbased fire prediction models (Field et al., 2015). The severity of the risk thresholds defined by the Canadian method described in Table 4.

Table 4. Interpretation of the values of the components of the FWI (Van Wagner CE, 1987)

\begin{tabular}{|l|l|l|l|l|l|}
\hline Indices & Low & Moderate & High & Very High & Extreme \\
\hline FFMC & $0-81$ & $81-88$ & $88-90.5$ & $\begin{array}{l}90.56- \\
92.4\end{array}$ & $92.5+$ \\
\hline DMC & $0-13$ & $13-28$ & $28-42$ & $42-63$ & $63+$ \\
\hline DC & $0-80$ & $80-210$ & $210-274$ & $274-360$ & $360+$ \\
\hline ISI & $0-4$ & $4-8$ & $8-11$ & $11-19$ & $19+$ \\
\hline BUI & $0-19$ & $19-34$ & $34-54$ & $54-77$ & $77+$ \\
\hline FWI & $0-5$ & $5-14$ & $14-21$ & $21-33$ & $33+$ \\
\hline
\end{tabular}

The values of the different components of the FWI were extracted from the 32 sites using the nearest neighbor method. A statistical analysis using a linear prediction model is used to define the performance of the two indices (components of FWI) to predict the burned areas calculated from the MODIS burned area products (Boschetti et al., 2009) and active fire (Giglo et al., 2016). The predictors are used to perform a leave-one-out cross-validated hindcast at lag 0 (predictors/predictands based on the same period). Then, the linear regression model is built for each month to be predicted, calculating the coefficients of the model with all the months in our database except the one that is predicted (ter Braak and Juggins, 1993; Birks, 1981). This method consists to take, for each month, all the values of the combined indices and that of the burned area, with the exception of the month that we wish to predict, and this for all months of our time series, and to compare the observed signal with that predicted by the linear model that combines regressions and their coefficients. The hind-cast is performed and correlated with the omitted observations. The FWI components (table 4) are then introduced in the multi-linear regression model as predictors and the terms were selected only if they reach the 0.05 significance level. Lagged correlations and model skills from lag-1 (one month before) to lag-5 (five months before) are evaluated and the results and discussions are explained in the next section. All statistical analysis and processing are performed as our own Matlab codes.

\section{Results and Discussion}

\subsection{Month-to-month Variability of Fire Activity}




\section{MInstitute Macrothin}

The monthly MODIS active fire and burned area are calculated for the 32 sites across Guinean, over the period 2003-2013 to investigate the fire spatial and temporal activity. Results show very remarkable differences regarding the variability of observed fire activity of each site without considering the human activity. Figure 3 presents the distribution over the 2003-2013 period of monthly bush fire activities and burned areas of the 32 sites. Many extra box-plot values are observed for almost all of the sites, meaning the local monthly temporal distribution of both bush fire and burned areas present strong local variability, with many extreme and unusual situations. This feature is more marked with the number of active fire than with the burned areas.

Figure 3a also reveals that the highest number of fire cases are observed in Kankan with a maximum of 1500 fire cases per month and within $25 \%$ of values higher than 750 cases, Beyla and Kouroussa with a maximum of 1100 cases per month for both sites, and within 25\% of the values higher than 400 and 600 cases respectively and finally Kérouané and Dubreka with a maximum of 1000 cases per month for both sites, with $25 \%$ of the recorded values higher than 400 cases of fire. The lowest values were recorded in Labé, Koubia, Touhgué, Lélouma, Siguiri, Fria, Dabola and Forécariah with a maximum less than 70 cases of fires per month. Regarding the burned areas, the highest values are noted over Siguiri and Kankan with a maximum of $8.10^{4}$ ha per month and within $25 \%$ of values higher than $5.10^{4}$ ha, Beyla, Tougué, Mali and Kérouané with a maximum of $5.10^{4}$ ha per month and within $25 \%$ of values higher than $2.10^{4}$ ha (Figure $3 \mathrm{~b}$ ). And for the lowest values of burned areas over the period, 2003 to 2013 are recorded in the N'Zérékoré, Koubia, Tougué, Lélouma, Macenta, Boffa, Kindia, Coyah, Labé, Fria, Dabola and Forécariah sites with maxima values less than $1,5.10^{3}$ ha per month. These results show that the Northern sites such as Kankan, Kérouané, kouroussa, Dinguiraye, are the most vulnerable to bushfires. A finding that is in agreement with the results of Barry et al., (2015). These sites are characterized by high temperatures recorded during the dry season (season of wildfires) that can reach more than $42^{\circ} \mathrm{C}$, with minimum rainfall, low relative humidity and a strong wind compared to the Southern sites. 


\section{Macrothink}
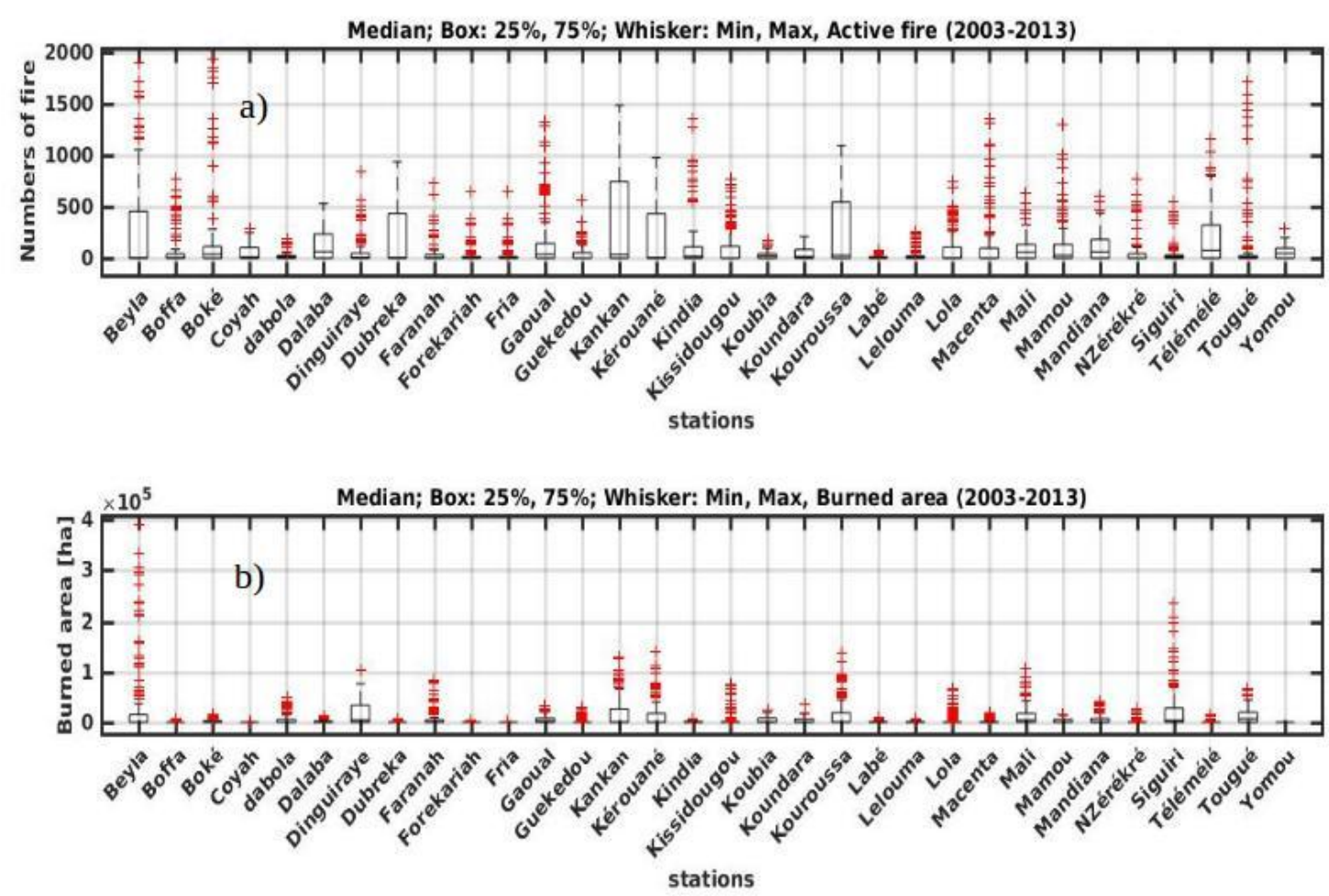

Figure 3. Number of active fires (a) and area burned (b) by site in Guinea, for the period of 2003 - to 2013

\subsection{Seasonal Cycle of Fire Activity}

Figure 4 presents the seasonal cycle of the number of actives fire as well as the burned areas based on the monthly climatology over the period 2003-2013 when data overall 32 sites have been averaged. As expected, no fired case is recorded by MODIS Aqua/TERRA combination during the monsoon period extending June to October (Figure 4a). In contrast, the highest numbers of fire are observed from January to April, with a monthly mean higher than 200 cases. The strongest peak is noted in April, with a maximum of 310 fire cases, within $25 \%$ of these cases higher than 300 cases. Also, a moderate number of cases are observed during May and November-December. These periods correspond to early fires corresponding to early dry season and late fires (late dry season respectively. Regarding the seasonal cycle of burned areas, likewise the number of active fire, zero surfaces is recorded (Figure 4b). Observed burned area increases from November to January and decrease from January to March. January is indexed as the month in which the burned area is strongest according to the high value of the burned areas median in this month. The maximum observed is around 3.9.10 ${ }^{4}$ ha, with $25 \%$ of values higher than $3.10^{4}$ ha.

One can see that seasonal cycles of the number of active fire and burned area are not correlated. The peak of the number of fire is noted in April (figure 4a) while that of the burned area in January (figure 4b). Indeed, November to January period is the beginning of the dry season, there are several burned areas even if the number of active fire is low. In April, the number of active fire is higher because at this period there is no humidity and the vegetation is dry according to the opinions of water and forest officers and field observations 
during this period. But this does not lead to a maximum of the burned area because there is no surface to be burned anymore due to the early burning by a small number of active fire in January for instance. Also, this dis-proportionality could also result from the fact that active fires are samples that correspond to the fires recorded during the passage of the satellite in contrast to the burned areas that are not dynamic over time.
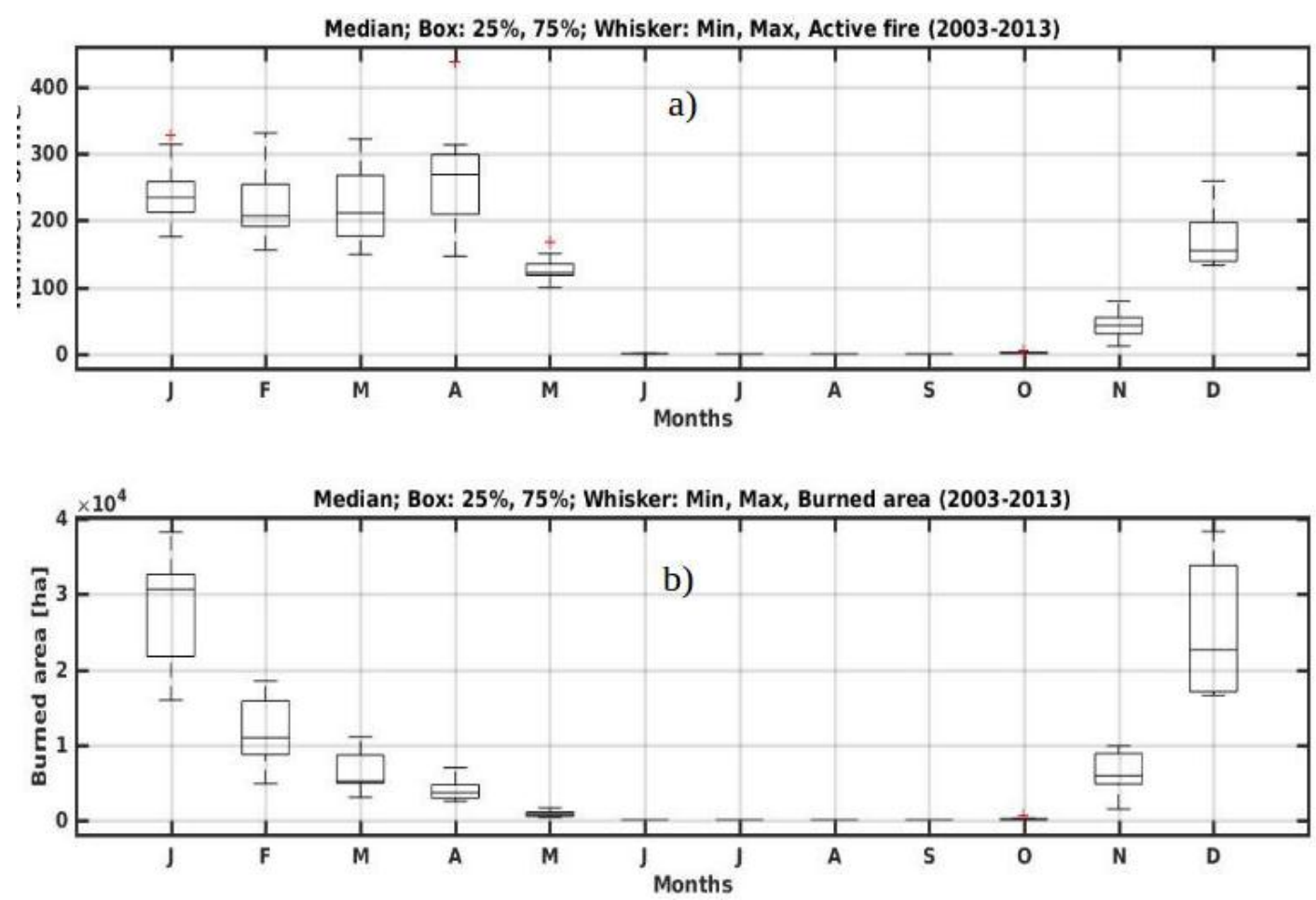

Figure 4. Number of active fires (a) and Area burned (b) by month in Guinea, for the 2003-2013 period

The spatial and temporal variabilities of observed fire activities (Figure 3 and Figure 4) demonstrate the importance of the implementation of forest fire warning systems in Guinea. Several studies on the variability of bush fires activity and fire emission show the ability of FWI components to characterize bush fire activity in some other areas (Amiro et al., 2005, Flannigan et al., 2005, Carvaillo et al., 2008, Giuseppe et al., 2018, Jain et al., 2018, Erickson et al., 2018). According to these authors, it is possible to investigate the predictability of active fires and burnt areas using the FWI components as predictors in addition.

Therefore, based on these findings, we have tried to assess the predictability of fire activity in Guinea using cross-validation multi-linear regression model and results are presented and discussed in the following section.

\subsection{Predictability of Fire Activity}

The predictability of fire activity is investigated using a multilinear regression model using combinations of a couple of FWI components as predictors and the number of active fire as well as burned areas as predictands. This analysis is applied to monthly time series using values from the 32 sites for each parameter. Tables 5 and 6 summarize the explained variance of the monthly burned area and monthly active fire respectively for 32 sites considered in this 
study. All components of the FWI (Figure 1) have been combined and combinations that lead to significant skills have been selected. These skills are ranked in Table 5 and 6 in increasing order of importance (percent explained variance). Concerned sites (Tables 5 and 6) are classified by alphabetic order. Two by two combinations: (FWI-FFMC, ISI-FFMC, BUIFFMC, DMC-FFMC, DC-FFMC, DC-DMC, DMC-FWI, DMC-BUI, ISI-BUI, ISI-DC, FWIDC, BUI-DC, BUI-FWI, ISI-FWI) have been used. And combinations with significant skill are selected through the multi-regression stepwise, for each site.

The explained variance ranges of the number of active fire, from 29\% (at Siguiri) to 98\% (at Kankan) (Table4) and for the burned area from 28\% (at Télémelé) to 79\% (at Kankan) (Table $6)$ are all highly significant $(\mathrm{P}<0.0001)$. The results obtained for the burned area are higher than those from the statistics given by the 2015 report of the DNEF. This is due to the fact that these statistics on the burned area do not concern all the regions of Guinea, in contrast to our analysis where the missing data are here taken into account. Also, the method used by DNEF to estimate areas burned is not mentioned in the report and the differences could come out from the methodology as well.

In the northern and central region, 15 out of the 32 sites involved in this research, cover $60.51 \%$ of the areas burned and $46.12 \%$ of the cases of active fire during the period from 2003 to 2013 with a very heterogeneous distribution. The largest cumulative area burned has been recorded at Beyla (15\% of burned area) while for the number of active fire, Kankan records the most important cases (9.58\% of the total number of fire cases).

The percentages of variances explained for the burned areas and for the number of active fire are more significant with combinations of DC, DMC, and FFMC (Fuel Moisture Codes) and ISI (Fire Behavior Code). For instance, the DMC-BUI combination in Kouroussa explains 82\% of the variance of the active fires and that of ISI-FWI explains $79 \%$ of the variance of burned area in the same location.

The results show strong performances of the linear model in the sites with a homogeneous distribution of the vegetation cover like the case of the regions of Upper Guinea where one finds vast expanses of Savannah. However, in areas with a heterogeneous vegetation cover (Savannah with trees), like Middle Guinea and Lower Guinea predictability gives significant values of performance but with lower skills. This could be explained by the fact that the code of fuel is not variable inside the $0.5^{\circ} * 0.5^{\circ}$ grid of the GFWED, and could reduce the precision in case that, inside the grid, the plant cover is non-homogeneous.

Tables 5 and 6 show that from one site to another, the combination of predictors with significant skills and strong explained variance of area burned and the number of active fire, differ significantly. Although most of the significant variables are found in all districts except Yomou, Labé, and Fria. For these sites, the burned areas could not be predicted with good skills. The results show the ability of the FWI components to predict active fire and burned areas across Guinea with highly significant performance and with several possible combinations for $90 \%$ of sites considered. In Faranah, Forékariah, Tougué, Télémelé, Labé, and Lélouma, the percentages of the variance of areas burned and the number of active fires is the lowest. This can be due to the fuel characteristics and the physical conditions surely 


\section{Macrothink}

Environmental Management and Sustainable Development

ISSN 2164-7682

2019, Vol. 8, No. 2

different from the fuel characteristics and the physical conditions related to the rest of the country (Carvaillo et al., 2008) and the homogeneity of vegetation cover.

Table 5. District monthly number of active fire explained variance $\left(\mathrm{r}^{2}\right)$ and variables selected, in order of importance, by stepwise regression

\begin{tabular}{|c|c|c|c|c|}
\hline Sites & Significant selected combinations & $\begin{array}{l}\text { Explained } \\
\text { variance } \\
\text { range }(\%)\end{array}$ & $\mathrm{N}$ & $\mathrm{P}$ \\
\hline Beyla & $\begin{array}{l}\text { ISI-DC, FWI-DC, ISI-FWI, DMC-BUI, DMC-FWI } \\
\end{array}$ & 75 to 79 & 132 & $<0.0001$ \\
\hline Boffa & ISI-BUI,, DMC-FWI, DMC-FFMC, ISI-DC, FWI-FFMC & 60 to 77 & 132 & $<0.0001$ \\
\hline Boké & FWI-DC, ISI-DC, DC-DMC & 38 to 43 & 132 & $<0.0001$ \\
\hline Coyah & $\begin{array}{l}\text { ISI-FFMC, FWI-FFMC, DMC-FFMC, ISI-DC, DC- } \\
\text { FFMC }\end{array}$ & 50 to 59 & 132 & $<0.0001$ \\
\hline Dabola & BUI-DC, FWI-DC, ISI-DC & 37 to 41 & 132 & $<0.0001$ \\
\hline Dalaba & DMC-FFMC, ISI,-FFMC, FWI-FFMC, BUI-FFMC & 67 to 78 & 132 & $<0.0001$ \\
\hline Dinguiraye & DMC-FFMC, DC-DMC, DMC-BUI & 34 to 50 & 132 & $<0.0001$ \\
\hline Dubréka & $\begin{array}{l}\text { ISI-FWI, ISI-FFMC, BUI-DC, DC-DMC, } \\
\text { FWI-FFMC, BUI-FFMC }\end{array}$ & 74 to 77 & 132 & $<0.0001$ \\
\hline Faranah & BUI-DC, FWI-DC, DC-DMC, ISI-DC & 31 to 36 & 132 & $<0.0001$ \\
\hline Forécariah & UI-DC, DC-DMC, BUI-FWI & to 37 & 132 & $<0.0001$ \\
\hline Fria & DC-DMC, BUI-DC, FWI-DC, ISI-DC & 33 to 41 & 132 & $<0.0001$ \\
\hline Gaoual & BUI-DC, FWI-DC, ISI-DC, DC-DMC, DC-FFMC & 39 to 59 & 132 & $<0.0001$ \\
\hline Guékédou & BUI-DC, FWI-DC, ISI-DC, DC-DMC, DC-FFMC & 56 to 77 & 132 & $<0.0001$ \\
\hline Kankan & DMC-BUI, FWI-DC, FWI-FFMC, ISI-FWI, DI & 079 & 132 & $<0.0001$ \\
\hline Kérouané & $\begin{array}{l}\text { ISI-DC, FWI-DC, BUI-DMC, } \\
\text { BUI-DC, DC-DMC }\end{array}$ & 72 to 81 & 132 & $<0.0001$ \\
\hline Kindia & BUI-DC, FWI-DC, DC-DMC, DC-FFMC & 37 to 46 & 132 & $<0.0001$ \\
\hline Kissidougou & BUI-DC, FWI-DC, ISI-DC, DC-DMC, DC-FFMC & 73 & 132 & $<0.0001$ \\
\hline Koubia & $\begin{array}{l}\text { DMC-BUI, FWI-DC, DC-FFMC, ISI-DC, } \\
\text { DMC-FWI, FWI-FFMC, ISI-FWI }\end{array}$ & 41 to 60 & 132 & $<0.0001$ \\
\hline Koundara & ISI-DC, FWI-DC, ISI-BUI, ISI-FWI, ISI-FFMC & 79 to 82 & 132 & $<0.0001$ \\
\hline Kouroussa & ISI-DC, FWI-DC, BUI-DC, DC-FFMC, DC-DMC & 77 to 81 & 132 & $<0.0001$ \\
\hline Labé & BUI-DC, DC-DMC, ISI-DC, FWI-DC, DC-FFMC & 39 to 47 & 132 & $<0.0001$ \\
\hline Lélouma & DC-DMC, BUI-DC, ISI-DC, FWI-DC & 42 to 46 & 132 & $<0.0001$ \\
\hline Lola & BUI-DC, DC-FFMC, DC-ISI, DC-FWI, DC-DMC & 72 to 73 & 132 & $<0.0001$ \\
\hline Macenta & , ISI-DC, FWI-DC, DC-FFMC & 50 to 60 & 132 & $<0.0001$ \\
\hline Mali & MC-BUI, DMC-FWI, ISI-FWI & 36 to 41 & 132 & $<0.0001$ \\
\hline Mamou & BUI-DC, FWI-DC, DC-DMC, ISI-DC, DC-FFMC & 41 to 51 & 132 & $<0.0001$ \\
\hline Mandiana & $\begin{array}{l}\text { BUI-FWI, DMC-FWI, FWI-FFMC, ISI-FFMC, } \\
\text { ISI-BUI, FWI-DC, ISI-FWI }\end{array}$ & 53 to 57 & 132 & $<0.0001$ \\
\hline N'Zérékoré & BUI-DC, ISI-DC, FWI-DC, DC-DMC & 45 to 49 & 132 & $<0.0001$ \\
\hline Siguiri & DMC-BUI, DC-DMC & 25 to 29 & 132 & $<0.0001$ \\
\hline Télémelé & C-FFMC, BUI-FFMC, DMC-FFMC, FWI-FFMC & 37 to 70 & 132 & $<0.0001$ \\
\hline Tougué & DMC-BUI, DC-DMC, BUI-DC, ISI-DC & 30 to 37 & 132 & $<0.0001$ \\
\hline Yomou & ISI-FFMC, FWI-FFMC, DMC-FFMC, BUI-FFMC & 29 to 34 & 132 & $<0.0001$ \\
\hline
\end{tabular}

Table 6. District monthly area burned explained variance $\left(\mathrm{r}^{2}\right)$ and variables selected, in order of importance, by stepwise regression

\begin{tabular}{|l|l|c|c|c|}
\hline Sites & Significant selected combinations & $\begin{array}{c}\text { Explained variance } \\
\text { range }(\%)\end{array}$ & $\mathrm{N}$ & $\mathrm{P}$ \\
\hline Beyla & FWI-DC, BUI-FWI, DMC-FWI, FWI-FFMC, ISI-FWI & 75 to 77 & 132 & $<0.0001$ \\
\hline Boffa & ISI-DC, DC-FFMC, FWI-DC & 39 to 40 & 132 & $<0.0001$ \\
\hline Boké & BUI-FFMC, FWI-FFMC, DMC-FFMC & 33 to 37 & 132 & $<0.0001$ \\
\hline Coyah & DC-FFMC & 19 & 132 & $<0.0001$ \\
\hline Dabola & ISI-DC, DC-FFMC, FWI-DC & 42 to 43 & 132 & $<0.0001$ \\
\hline
\end{tabular}




\begin{tabular}{|c|c|c|c|c|}
\hline Dalaba & DC-FFMC, FWI-FFMC, BUI-FFMC & 24 to 32 & 132 & $<0.0001$ \\
\hline Dinguiraye & FWI-DC, ISI-FWI, BUI-FWI-FWI-FFMC, DC-DMC & 54 to 65 & 132 & $<0.0001$ \\
\hline Dubréka & ISI-FWI, ISI-BUI, FWI-DMC & 20 to 22 & 132 & $<0.0001$ \\
\hline Faranah & BUI-FWI, FWI-DC, ISI-DC, FWI-FFMC & 42 to 49 & 132 & $<0.0001$ \\
\hline Forécariah & DC-FFMC, ISI-FWI & 22 to 25 & 132 & $<0.0001$ \\
\hline Fria & & & 132 & $<0.0001$ \\
\hline Gaoual & DC-FFMC, DC-DMC, ISI-DC, FWI-DC, BUI-DC & 46 to 47 & 132 & $<0.0001$ \\
\hline Guékédou & $\begin{array}{l}\text { FWI-DC, BUI-DC, BUI-FFMC, FWI-FFMC, DC- } \\
\text { DMC, ISI-BUI, BUI-FWI }\end{array}$ & 54 to 57 & 132 & $<0.0001$ \\
\hline Kankan & ISI-FWI, FWI-DC, FWI-FFMC, DMC-FWI, BUI-FWI & 74 to 79 & 132 & $<0.0001$ \\
\hline Kérouané & $\begin{array}{l}\text { DMC-FWI，BUI-FWI，ISI-FFMC，ISI-DC，ISI-FWI, } \\
\text { ISI-BUI }\end{array}$ & 69 to 74 & 132 & $<0.0001$ \\
\hline Kindia & $\begin{array}{l}\text { ISI-FWI, ISI-FFMC, DMC-FFMC, Fwi-FFMC, BUI- } \\
\text { FFMC }\end{array}$ & 23 to 25 & 132 & $<0.0001$ \\
\hline Kissidougou & $\begin{array}{l}\text { BUI-FFMC, ISI-FWI, DMC-FFMC, DC-FFMC, FWI- } \\
\text { FFMC }\end{array}$ & 59 to 61 & 132 & $<0.0001$ \\
\hline Koubia & $\begin{array}{l}\text { DC-FFMC, ISI-DC, FWI-DC, FWI-FFMC, ISI-FFMC, } \\
\text { ISI-BUI }\end{array}$ & 28 to 41 & 132 & $<0.0001$ \\
\hline Koundara & $\begin{array}{l}\text { ISI-DC, FWI-DC, ISI-BUI, BUI-FWI, ISI-FWI, DMC- } \\
\text { FWI, ISI-FFMC }\end{array}$ & 56 to 67 & 132 & $<0.0001$ \\
\hline Kouroussa & $\begin{array}{l}\text { ISI-FWI，ISI-DC，ISI-FFMC，ISI-BUI，FWI-FFMC， } \\
\text { DMC-FWI，DMC-BUI }\end{array}$ & 65 to 70 & 132 & $<0.0001$ \\
\hline Labé & DC-FFMC & 16 & 132 & $<0.0001$ \\
\hline Lélouma & DMC-FFMC, BUI-FFMC & 22 to 25 & 132 & $<0.0001$ \\
\hline Lola & $\begin{array}{l}\text { ISI-DC，ISI-FFMC，ISI-FWI，FWI-FFMC，ISI-BUI, } \\
\text { DMC-FWI }\end{array}$ & 62 to 65 & 132 & $<0.0001$ \\
\hline Macenta & $\begin{array}{l}\text { ISI-FFMC，ISI-DC，ISI-BUI，ISI-FWI，DMC-FWI， } \\
\text { DMC-BUI, FWI-FFMC }\end{array}$ & 56 to 61 & 132 & $<0.0001$ \\
\hline Mali & DC-FFMC, BUI-FWI, ISI-BUI, FWI-DC & 32 to 42 & 132 & $<0.0001$ \\
\hline Mamou & $\begin{array}{l}\text { ISI-FWI, ISI-BUI, ISI-FFMC, DC-FFMC, ISI-DC, } \\
\text { DMC-FFMC, FWI-FFMC }\end{array}$ & 47 to 53 & 132 & $<0.0001$ \\
\hline Mandiana & $\begin{array}{l}\text { BUI-FWI, FWI-DC, ISI-BUI, FWI-FFMC, ISI-FFMC, } \\
\text { DMC-FWI, ISI-DC }\end{array}$ & 52 to 54 & 132 & $<0.0001$ \\
\hline N'Zérékoré & $\begin{array}{l}\text { ISI-FFMC, ISI-DC, DMC-FWI， ISI-BUI， ISI-FWI, } \\
\text { FWI-FFMC, FWI-DC }\end{array}$ & 56 to 59 & 132 & $<0.0001$ \\
\hline Siguiri & ISI-BUI, BUI-FWI, FWI-DC, ISI-DC & 37 to 41 & 132 & $<0.0001$ \\
\hline Télémelé & ISI-DC, FWI-DC, DMC-DC & 26 to 28 & 132 & $<0.0001$ \\
\hline Tougué & DC-FFMC, ISI-DC, FWI-DC, ISI-FWI, ISI-FFMC & 24 to 36 & 132 & $<0.0001$ \\
\hline Yomou & & & 132 & $<0.0001$ \\
\hline
\end{tabular}

Based on the average monthly values of the number of active fire cases (table 5) and areas burned (table 6) for the 32 sites, all combinations of FWI components present very significant skill, with explained percentages of variance range between 75 and $84 \%$ and between 29 and $77 \%$ respectively. Figures $5 \mathrm{a}$ and $5 \mathrm{~b}$ show results from the best combinations of predictors for active fire ( FWI-DC) and burned area (FWI-BUI).

However, the analysis of simple correlations between the FWI components and the burned and active fires shows that the FWI (better correlated) alone explains $82 \%$ of the variance of the active fires whereas the FFMC (better correlated) explains 50\% of the variance of burned areas. This shows that active fires are easier to characterize with the fuel moisture codes and as are the burned areas with the fire behavior indices.

A qualitative analysis of the relationship between best-selected combinations and both active fire and burned areas (figure 5) shows that the multi-linear regression model is able to predict fire in Guinea on monthly timescale with highly significance skills at lag 0 . The predicted and 
observed plots (figure 5a and figure 5b) show the same evolution with often underestimation of the burned area and active fire at the beginning of the year during the whole period 2003 to 2013 except the year 2005 where both have been over-estimated and 2011, when burned area alone are overestimated. The underestimates and overestimates bias of active fire and area burned in Guinea seen in Figure 5, can be explained by human activities. For periods of overestimation of burned areas and active fire, the risk of starting and spreading fires has been high, but the human activities were less intense and conversely when we have an underestimation.

The percentages of unexplained variances can be attributed to the homogeneity of the vegetation cover. In sites where vegetation cover is homogeneous, the percentages of variances explained are the most important. The spatial resolution of the FWI data could also smooth the small scales details. The prevention and sensitization campaigns that the National Directorate of Water and Forests (DEF), and the Center for Observation, Monitoring and Environmental Information (COSIE) and their local authorities implemented at the beginning of fire period is also another aspect that can influence the forest fires statistics and bush fire ignition according to Carvailho et al. (2008).
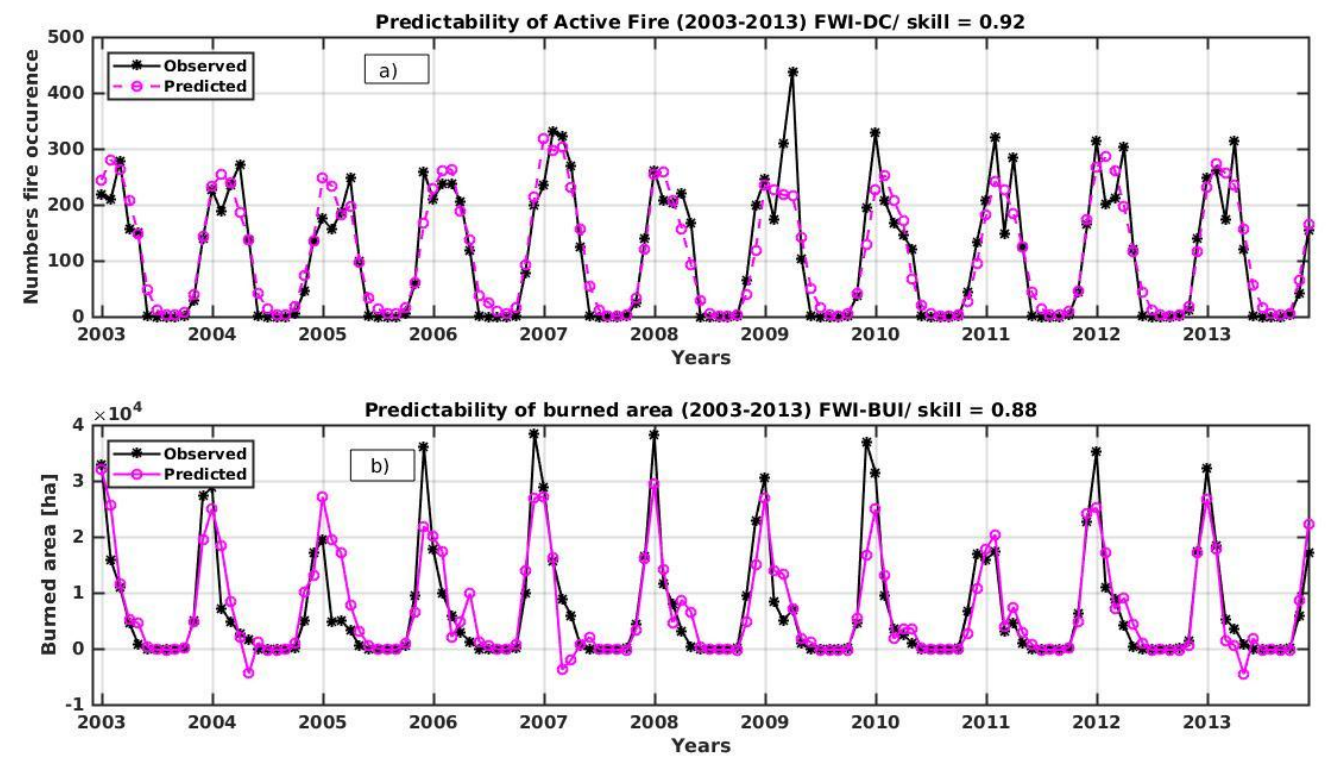

Figure 5. Observed (black line) and predicted (pink line) monthly active fire (a) and burned area (b) between 2003 and 2013, over Guinea

In figure. 6, the same model is extended to take into account the pairs of selected predictors, FWI-DC and FWI-BUI, for the active fires and the burned areas respectively, at lag0 (January), then at lag-1 (December of last year) until-5 (June of last year) successively. In figure 6, the shifted correlations between predictands (active fire and burned areas) and predictors (selected FWI components) are provided with bars, while the skill scores of the multi-regression model are represented with stars. For December, active fire events, appear significant predictable by FWI and DC predictors down to 3 months in advance (Figure. 6a, 95\% confidence level). The model is then able to predict in, October the situation in 


\section{Macrothink}

December, based on FWI and DC as predictors. This result is also in agreement with the shifted correlation values, which are statistically significant (same confidence interval) for both DC (thin bars) up to lag-1 (one month before) and FWI (wide bars) until lag-2 (two months before). Figure 6a also shows that where we have positive correlations between the active fires and the two predictors, model performance is significant.

For burned areas, the skill of the predictability of the situation in January (based on the FWI and BUI predictors) remains significant just on 1 month in advance (November) (Fig. 6b). There is also a rapid decrease in the correlations between burned areas and the two predictors (FWI and BUI). As with active fires, we note that significant performance is observed when we have significant correlations between area burned and predictors. The difficulty of predicting areas burned more than a month in advance can be attributed to the fact that they are not dynamic over time (these are not the events but rather the consequences of active fires). These results are therefore extremely important given the fact that the model has the ability to predict active fire events (cause of burned areas observed) down to 3 months in advance, thus providing the opportunity to take fire prevention measures.
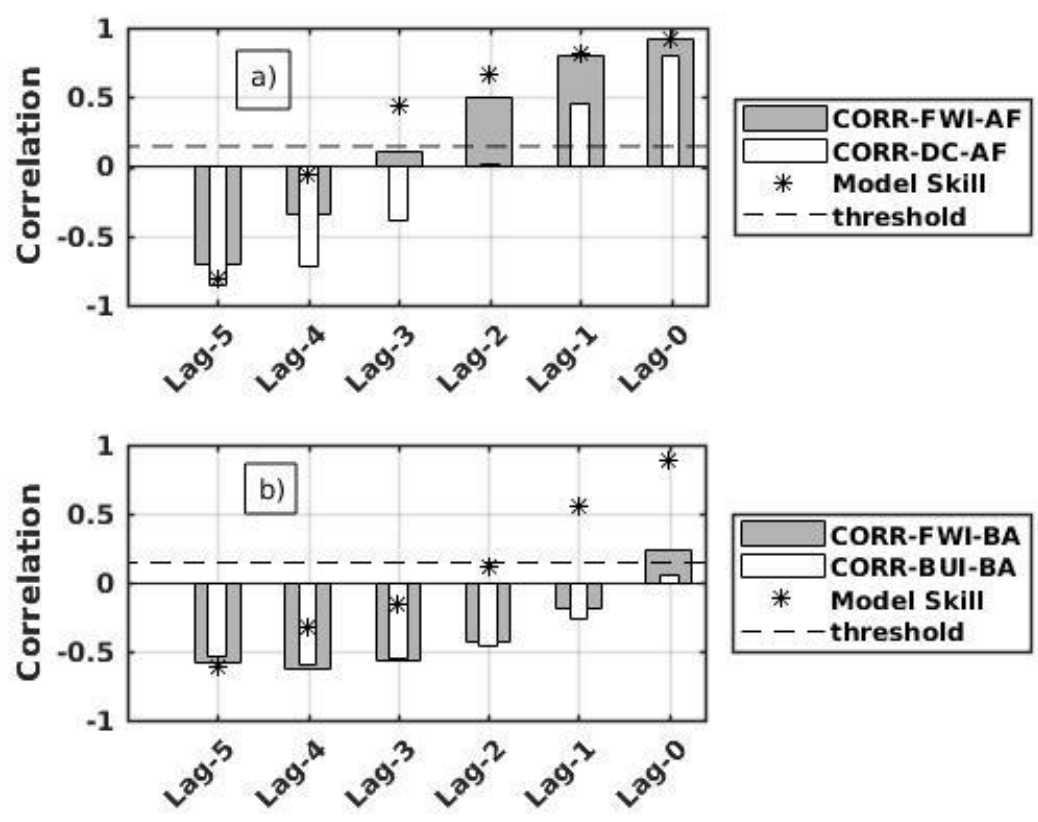

Figure 6. Lagged correlation and cross-validation hindcast of Bush fire: (a) Active fire, (b) Burned area for January. Bars denote lagged correlations on a monthly basis between January active fire and burned area (predictands) and preceding monthly FWI, DC, and BUI (predictors). The dashed horizontal line delimits the statistical significance (95\% confidence level) for correlation. Markers are the multi-linear regression model skill

\section{Conclusion}

This study investigates the relationship between Global Fire WEather Index Database components and monthly burned area and active fire recorded by MODIS Aqua/TERRA combination overall Guinea considering 32 sites. Statistical analysis through a multiple linear 
regression model evaluated the predictability of active fires and burned areas in these stations and across the country using two-by-two combinations of Fire Weather Index (FWI) components of predictors. The combinations of Drought Code (DC), Initial Spread Index (ISI), Fine Fuel Moisture Code (FFMC), Duff Moisture Code (DMC), The Buildup Index (BUI) and FWI components have been selected by the linear multi-regression stepwise model based on the skill of the model to predict the fire activity. All two-by-two combinations of these components show very significant skill at lag 0 for both active fires and burned areas, with a percentage of variances between 75 and $84 \%$ and between 29 and $77 \%$ respectively. Results also showed that active fires are more related to fire behavior indices while the burned areas are related to the fine fuel moisture codes.

In the latest way, the application of lagged correlations and the evaluation of the stepwise multi-linear regression model skills from lag0 (same month) to lag-5 (five months before) has been computed based on the month of January for active fire and burned areas. Monthly FWI and DC and monthly FWI and BUI for the active fire and burned areas respectively have been considered as predictors. Results show that the active fire events can be predicted several months in advice using FWI and DC as predictors and the burned areas can be predicted just one month in advice using FWI and BUI as predictors. These may have implications on seasonal forecasting of active fire events specially. These are also a stepping stone in supporting Guinea's water and forest services in protecting ecosystems and biodiversity against the impacts of bush fires. These results also open up perspectives on the possibility of using forecasting models to project future and past events in order to better understand the long-term effects of bush fire on ecosystems, biodiversity and on the pollution of the environment.

\section{Acknowledgment}

The authors thank the French government for the PhD grant for Mamadou Baillo and the financing of research training at the "Laboratoire de Physique de l'Atmosphère et de l'Océan (LPAO-SF)" (Senegal). This institution is also greatly acknowledged for all the supports and the free software availability. The authors are also thankful to NASA for the data availability without fees. Our thanks also to the anonymous reviewers for their comments which helped to improve the quality of this paper.

\section{References}

Albertson, K., Aylen, J., Cavan, G., \& McMorrow, J. (2009). Forecasting the outbreak of moorland wildfires in the English Peak District. Journal of Environmental Management, 90(8), 2642-2651. https://doi.org/10.1016/j.jenvman.2009.02.011

Alonso-Betanzos, A., Fontenla-Romero, O., Guijarro-Berdiñas, B., Hernández-Pereira, E., Andrade, M. I. P., Jiménez, E., ... Carballas, T. (2003). An intelligent system for forest fire risk prediction and fire fighting management in Galicia. Expert systems with applications, 25(4), 545-554. https://doi.org/10.1016/S0957-4174(03)00095-2

Amiro, B. D., Logan, K. A., Wotton, B. M., Flannigan, M. D., Todd, J. B., Stocks, B. J., \& Martell, D. L. (2005). Fire weather index system components for large fires in 
the Canadian boreal forest. International Journal of Wildland Fire, 13(4), 391-400. https://doi.org/10.1071/WF03066

Archibald, S., Lehmann, C. E., Gómez-Dans, J. L., \& Bradstock, R. A. (2013). Defining pyromes and global syndromes of fire regimes. Proceedings of the National Academy of Sciences, 110(16), 6442-6447. https://doi.org/10.1073/pnas.1211466110

Barry, M. B., Badiane, D., Diakhaté, M., Sall, S. M., Senghor, H., \& Millimono, T. N. (2018). Variability and predictability of bush fire in Guinea on inter-annual and multi-year timescales based on NDVI-MODIS datasets analysis. African Journal of Environmental Science and Technology, 12(12), 514-522. https://doi.org/10.5897/AJEST2018.2562

Barry, M. B., Badiane, D., Sall, S. M., Balde, M. L., Millimono, T., Diaby, I., \& Diallo, D. (2015). APPORT D'UNE METHODE DE DETECTION ET D'ESTIMATION DES SURFACES BRULEES PAR IMAGERIE MODIS: APPLICATION AUX SAVANES GUINEENNES. REVUE SCIENTIFIQUE DE L'UNIVERSITÉ JULIUS N'YÉRÉRÉ DE KANKAN.

Bedia, J., Herrera, S., Gutiérrez, J. M., Benali, A., Brands, S., Mota, B., \& Moreno, J. M. (2015). Global patterns in the sensitivity of burned area to fire-weather: Implications for climate change. Agricultural and Forest Meteorology, 214, 369-379. https://doi.org/10.1016/j.agrformet.2015.09.002

Birks, H. J. B. (1981). The use of pollen analysis in the reconstruction of the past climates: a review. In Wigley TML, Ingram MJM, Farler G editors Climate and history Cambridge: Cambridge University Press. pp. 111-138.

Boschetti, L. (2018). MODIS Collection 5.1 Burned Area Product-MCD45. User's Guide Version 3.0. 1.

Boulanger, Y., Gauthier, S., Burton, P. J. (2014). A refinement of models projecting future Canadian fire regimes using homogeneous fire regime zones. Canadian journal of forest research, 44(4), 365-376. https://doi.org/10.1139/cjfr-2013-0372

Carvalho, A., Flannigan, M. D., Logan, K., Miranda, A. I., \& Borrego, C. (2008). Fire activity in Portugal and its relationship to weather and the Canadian Fire Weather Index System. International Journal of Wildland Fire, 17(3), 328-338. https://doi.org/10.1071/WF07014

Chen, M., Shi, W., Xie, P., Silva, V. B., Kousky, V. E., Wayne Higgins, R., \& Janowiak, J. E. (2008). Assessing objective techniques for gauge-based analyses of global daily precipitation. Journal of Geophysical Research: Atmospheres, 113(D4). https://doi.org/10.1029/2007JD009132

Cheng, D., Rogan, J., Schneider, L., \& Cochrane, M. (2013). Evaluating MODIS active fire products in subtropical Yucatán forest. Remote Sensing Letters, 4(5), 455-464. https://doi.org/10.1080/2150704X.2012.749360

Chuvieco, E., Giglio, L., \& Justice, C. (2008) Global characterization of fire activity: toward 
defining fire regimes from Earth observation data. Global Change Biology, 14, 14881502. https://doi.org/10.1111/j.1365-2486.2008.01585.x

Costafreda-Aumedes, S., Comas, C., \& Vega-Garcia, C. (2018). Human-caused fire occurrence modelling in perspective: a review. International journal of wildland fire, 26(12), 983-998. https://doi.org/10.1071/WF17026

Csiszar, I. A., Morisette, J. T., \& Giglio, L. (2006). Validation of active fire detection from moderate-resolution satellite sensors: the MODIS example in northern Eurasia. IEEE Transactions on Geoscience and Remote Sensing, 44(7), 1757-1764. https://doi.org/10.1109/TGRS.2006.875941

Davies, G. M., \& Legg, C. J. (2016). Regional variation in fire weather controls the reported occurrence of Scottish wildfires. PeerJ., 4, e2649. https://doi.org/10.7717/peerj.2649

De Groot, W. J., Field, R. D., Brady, M. A., Roswintiarti, O., \& Mohamad, M. (2007). Development of the Indonesian and Malaysian fire danger rating systems. Mitigation and $\begin{array}{lllll}\text { Adaptation Strategies for Global } & \text { Change, } & 12(1), & 165 .\end{array}$ https://doi.org/10.1007/s11027-006-9043-8

De Klerk, H. (2008). A pragmatic assessment of the usefulness of the MODIS (Terra and Aqua) 1-km active fire (MOD14A2 and MYD14A2) products for mapping fires in the fynbos biome. International Journal of Wildland Fire, 17(2), 166-178. https://doi.org/10.1071/WF06040

Doerr, S. H., \& Santín, C. (2016). Global trends in wildfire and its impacts: perceptions versus realities in a changing world. Philosophical Transactions of the Royal Society B: Biological Sciences, 371(1696), 20150345. https://doi.org/10.1098/rstb.2015.0345

Dowdy, A. J., Mills, G. A., Finkele, K., \& de Groot, W. (2009). Australian fire weather as represented by the McArthur forest fire danger index and the Canadian forest fire weather index. Centre for Australian Weather and Climate Research, Melbourne, Australia, Tech. Rep.

Dupuy, C. (1968). Rubidium et caesium dans biotite, sanidine et verre des ignimbrites de Toscane (Italie). Chemical Geology, 3(4), 281-291. https://doi.org/10.1016/0009-2541(68)90033-8

Erickson, M. J., Colle, B. A., \& Charney, J. J. (2018). Evaluation and Postprocessing of Ensemble Fire Weather Predictions over the Northeast United States. Journal of Applied Meteorology and Climatology, 57(5), 1135-1153. https://doi.org/10.1175/JAMC-D-170180.1

Field, R. D., Spessa, A. C., Aziz, N. A., Camia, A., Cantin, A., Carr, R., ... Pappenberger, F. (2015). Development of a global fire weather database. Natural Hazards and Earth System Sciences, 15(6), 1407-1423. https://doi.org/10.5194/nhess-15-1407-2015

Flannigan, M. D., Logan, K. A., Amiro, B. D., Skinner, W. R., \& Stocks, B. J. (2005). Future area burned in Canada. Climatic change, 72(1-2), 1-16. 
https://doi.org/10.1007/s10584-005-5935-y

Freeborn, P. H., Wooster, M. J., Roy, D. P., \& Cochrane, M. A. (2014). Quantification of MODIS fire radiative power (FRP) measurement uncertainty for use in satellite - based active fire characterization and biomass burning estimation. Geophysical Research Letters, 41(6), 1988-1994. https://doi.org/10.1002/2013GL059086

Giglio, L. (2010). MODIS collection 5 active fire product user"s guide version 24 Science Systems and Applications Inc.

Giglio, L. (2015). Modis collection 6 active fire product user's guide revision A. Unpublished Manuscript, Department of Geographical Sciences, University of Maryland. [Online] Available:

https://lpdaac.usgs.gov/sites/default/files/public/product_documentation/mod14_user_guide.p df

Giglio, L., Descloitres, J., Justice, C. O., \& Kaufman, Y. J. (2003). An enhanced contextual fire detection algorithm for MODIS. Remote sensing of environment, 87(2-3), 273-282. https://doi.org/10.1016/S0034-4257(03)00184-6

Giglio, L., Schroeder, W., \& Justice, C. O. (2016). The collection 6 MODIS active fire detection algorithm and fire products. Remote Sensing of Environment, 178, 31-41. https://doi.org/10.1016/j.rse.2016.02.054

Giuseppe, F. D., Rémy, S., Pappenberger, F., \& Wetterhall, F. (2018). Using the Fire Weather Index (FWI) to improve the estimation of fire emissions from fire radiative power (FRP) observations. Atmospheric Chemistry and Physics, 18(8), 5359-5370. https://doi.org/10.5194/acp-18-5359-2018

Guiterman, C. H., Margolis, E. Q., Allen, C. D., Falk, D. A., \& Swetnam, T. W. (2018). Long-term persistence and fire resilience of oak shrubfields in dry conifer forests of northern New Mexico. Ecosystems, 21(5), 943-959. https://doi.org/10.1007/s10021-017-0192-2

Hagmann, R. K., Stevens, J. T., Lydersen, J. M., Collins, B. M., Battles, J. J., Hessburg, P. F., ... Franklin, J. F. (2018). Improving the use of early timber inventories in reconstructing historical dry forests and fire in the western United States: Comment. Ecosphere, 9(7), e02232. https://doi.org/10.1002/ecs2.2232

Hantson, S., Padilla, M., Corti, D., \& Chuvieco, E. (2013). Strengths and weaknesses of MODIS hotspots to characterize global fire occurrence. Remote Sensing of Environment, 131, 152-159. https://doi.org/10.1016/j.rse.2012.12.004

Hawbaker, T. J., Radeloff, V. C., Syphard, A. D., Zhu, Z., \& Stewart, S. I. (2008). Detection rates of the MODIS active fire product in the United States. Remote Sensing of Environment, 112(5), 2656-2664. https://doi.org/10.1016/j.rse.2007.12.008

He, L., \& Li, Z. (2011). Enhancement of a fire-detection algorithm by eliminating solar contamination effects and atmospheric path radiance: Application to MODIS data. International journal of remote sensing, 32(21), 6273-6293. 
https://doi.org/10.1080/01431161.2010.508057

Hu, T., \& Zhou, G. (2014). Drivers of lightning-and human-caused fire regimes in the Great Xingan Mountains. Forest ecology and management, 329, 49-58. https://doi.org/10.1016/j.foreco.2014.05.047

Inoue, J., Okuyama, C., \& Takemura, K. (2018). Long-term fire activity under the East Asian monsoon responding to spring insolation, vegetation type, global climate, and human impact inferred from charcoal records in Lake Biwa sediments in central Japan. Quaternary Science Reviews, 179, 59-68. https://doi.org/10.1016/j.quascirev.2017.11.007

Jain, P., Wang, X., \& Flannigan, M. D. (2018). Trend analysis of fire season length and extreme fire weather in North America between 1979 and 2015. International Journal of Wildland Fire, 26(12), 1009-1020. https://doi.org/10.1071/WF17008

Jeffrey, S. T., \& Humphrey, G. F. (1975). New spectrophotometric equations for determining chlorophylls a, b, c1 and c2 in higher plants, algae and natural phytoplankton. Biochemie und physiologie der pflanzen, 167(2), 191-194. https://doi.org/10.1016/S0015-3796(17)30778-3

Karouni, A., Daya, B., \& Chauvet, P. (2014). APPLYING DECISION TREE ALGORITHM AND NEURAL NETWORKS TO PREDICT FOREST FIRES IN LEBANON. Journal of Theoretical \& Applied Information Technology, 63(2).

Knorr, W., Kaminski, T., Arneth, A., \& Weber, U. (2014). Impact of human population density on fire frequency at the global scale. Biogeosciences, 11(4), 1085-1102. https://doi.org/10.5194/bg-11-1085-2014

Krawchuk, M. A., Moritz, M. A., Parisien, M. A., Van Dorn, J., \& Hayhoe, K. (2009). Global pyrogeography: the current and future distribution of wildfire. PloS one, 4(4), e5102. https://doi.org/10.1371/journal.pone.0005102

Lozano, F. J., Suárez-Seoane, S., \& de Luis, E. (2007). Assessment of several spectral indices derived from multi-temporal Landsat data for fire occurrence probability modelling. Remote Sensing of Environment, 107(4), 533-544. https://doi.org/10.1016/j.rse.2006.10.001

Maier, S. W., Russell-Smith, J., Edwards, A. C., \& Yates, C. (2013). Sensitivity of the MODIS fire detection algorithm (MOD14) in the savanna region of the Northern Territory, Australia. ISPRS journal of photogrammetry and remote sensing, 76, 11-16. https://doi.org/10.1016/j.isprsjprs.2012.11.005

Mbow, C. (2000). Caracteristiques spatio-temporelles des feux de brousse et de leur relation avec la vegetation dans le parc national du Niokolo Koba (sud-est du Senegal).

Merrill, D. F., \& Alexander, M. E. (1987). Glossary of forest fire management terms.

Miller, R. F., Chambers, J. C., Pyke, D. A., Pierson, F. B., \& Williams, C. J. (2013). A review of fire effects on vegetation and soils in the Great Basin Region: response and ecological site characteristics (p. 126). Fort Collins, CO, USA: United States Department of Agriculture, Forest Service, Rocky Mountain Research Station. 
Millimono, T. N., Sall, S. M., Badiane, D., Bah, A., Diakhate, M., Toure, I., ... Diaby, I. (2017). Analysis of bushfires spatial and temporal variability in Guinea. Atmospheric and Climate Sciences, 7(04), 463. https://doi.org/10.4236/acs.2017.74034

Padilla, M., \& Vega-García, C. (2011). On the comparative importance of fire danger rating indices and their integration with spatial and temporal variables for predicting daily humancaused fire occurrences in Spain. International Journal of Wildland Fire, 20(1), 46-58. https://doi.org/10.1071/WF09139

Preisler, H. K., Brillinger, D. R., Burgan, R. E., \& Benoit, J. W. (2004). Probability based models for estimation of wildfire risk. International Journal of wildland fire, 13(2), 133-142. https://doi.org/10.1071/WF02061

Prestemon, J. P., \& Butry, D. T. (2005). Time to burn: modeling wildland arson as an autoregressive crime function. American journal of agricultural economics, 87(3), 756-770. https://doi.org/10.1111/j.1467-8276.2005.00760.x

Reed-Dustin, C. M. (2015). Long-term Fire Effects on Plant Succession and Exotic Weeds in Protected Area Sagebrush Steppe, John Day Fossil Beds National Monument, Oregon.

Ressl, R., Lopez, G., Cruz, I., Colditz, R. R., Schmidt, M., Ressl, S., \& Jiménez, R. (2009). Operational active fire mapping and burnt area identification applicable to Mexican Nature Protection Areas using MODIS and NOAA-AVHRR direct readout data. Remote Sensing of Environment, 113(6), 1113-1126. https://doi.org/10.1016/j.rse.2008.10.016

Roy, D. P. (1999). Multi-temporal active-fire based burn scar detection algorithm. International Journal of Remote Sensing, 20(5), 1031-1038. https://doi.org/10.1080/014311699213073

Roy, D. P., Jin, Y., Lewis, P. E., \& Justice, C. O. (2005). Prototyping a global algorithm for systematic fire-affected area mapping using MODIS time series data. Remote sensing of environment, 97(2), 137-162. https://doi.org/10.1016/j.rse.2005.04.007

Roy, D. P., Lewis, P. E., \& Justice, C. O. (2002). Burned area mapping using multi-temporal moderate spatial resolution data-A bi-directional reflectance model-based expectation approach. Remote sensing of environment, 83(1-2), 263-286. https://doi.org/10.1016/S0034-4257(02)00077-9

Sakr, G. E., Elhajj, I. H., \& Mitri, G. (2011). Efficient forest fire occurrence prediction for developing countries using two weather parameters. Engineering Applications of Artificial Intelligence, 24(5), 888-894. https://doi.org/10.1016/j.engappai.2011.02.017

Scholze, M., Knorr, W., Arnell, N. W., \& Prentice, I. C. (2006). A climate-change risk analysis for world ecosystems. Proceedings of the National Academy of Sciences, 103(35), 13116-13120. https://doi.org/10.1073/pnas.0601816103

Schroeder, W., Prins, E., Giglio, L., Csiszar, I., Schmidt, C., Morisette, J., \& Morton, D. (2008). Validation of GOES and MODIS active fire detection products using ASTER and ETM+ data. Remote Sensing of Environment, 112(5), 2711-2726. 
https://doi.org/10.1016/j.rse.2008.01.005

Sheehan, L., \& Hewitt, K. (1969). A pilot survey of global natural disasters of the past twenty years. Natural Hazard Research.

Sow, M. (2012). Caractrisation du risque de feu de brousse dans les savanes du Sngalpar approche exprimentale et par tldtection. PhD thesis, Universit Cheikh Anta Diop (UCAD).

Stocks, B. J., Lynham, T. J., Lawson, B. D., Alexander, M. E., Wagner, C. V., McAlpine, R. S., \& Dube, D. E. (1989). Canadian forest fire danger rating system:an overview. The Forestry Chronicle, 65(4), 258-265. https://doi.org/10.5558/tfc65258-4

Tanpipat, V., Honda, K., \& Nuchaiya, P. (2009). MODIS hotspot validation over Thailand. Remote Sensing, 1(4), 1043-1054. https://doi.org/10.3390/rs 1041043

Ter Braak, C. J., \& Juggins, S. (1993). Weighted averaging partial least squares regression (WA-PLS): an improved method for reconstructing environmental variables from species assemblages. In Twelfth International Diatom Symposium (pp. 485-502). Springer, Dordrecht. https://doi.org/10.1007/978-94-017-3622-0_49

Turner, J. A., \& Lawson, B. D. (1978). Weather in the Canadian forest fire danger rating system. A user guide to national standards and practices.

Valéa, F. (2010). Etudes des feux de brousse au Burkina-Faso: approches multi-échelles des feux actifs et des surfaces brûlées (Doctoral dissertation, Caen).

Van Wagner, C. E., \& Forest, P. (1987). Development and structure of the canadian forest fireweather index system. In Can. For. Serv., Forestry Tech. Rep.

Van Wagner, C. E., \& Pickett, T. L. (1985). Equations and FORTRAN program for the Canadian forest fire weather index system (Vol. 33).

Wang, W., Qu, J. J., Hao, X., Liu, Y., \& Sommers, W. T. (2007). An improved algorithm for small and cool fire detection using MODIS data: A preliminary study in the southeastern United States. Remote sensing of Environment, 108(2), 163-170. https://doi.org/10.1016/j.rse.2006.11.009

Wotton, B. M., Nock, C. A., \& Flannigan, M. D. (2010). Forest fire occurrence and climate change in Canada. International Journal of Wildland Fire, 19(3), 253-271. https://doi.org/10.1071/WF09002

\section{Disclaimer}

Copyright for this article is retained by the author(s), with first publication rights granted to the journal.

This is an open-access article distributed under the terms and conditions of the Creative Commons Attribution license (http://creativecommons.org/licenses/by/3.0/). 